\title{
自律的避難のための水害リスクコミュニケーション支援システムの開発*
}

\section{A Flood Risk Communication Support System to Promote Safe Autonomous Evacuation*}

\author{
川嶌健一**・多々納裕一***・畑山満則*** \\ By Kenichi KAWASHIMA** • Hirokazu TATANO*** • Michinori HATAYAMA***
}

\section{1.はじめに}

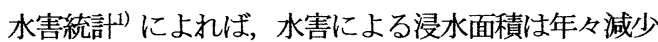
してきているが，単位浸水面積当たりの被害額である 「水害密度」は上昇傾向にある。このため, 水害による 被害額は, 必ずしも減少してきているわけではない。こ れは，河川の氾濫原における人口・資産の，水害に対す る脆弱性が軽減されてきているとは言い難いことを物語 っている。

集中豪雨等によって都市部で河川の疎通能力を上回る 規模の洪水が発生し，溢水・破堤に至って，人的・物的 被害が発生した事例が見られる例社)。ハード対策によ って全ての洪水被害を防ぐことはできないが，ソフト詨 策の充実によって人的な被害をより一層低下させること は可能であろう。人的被害軽減のためには先ず持って, 安全な避難を実現する体制を確立する必要がある。これ に関連して昨今, 行政による避難歓告や避難指示の発表 のタイミングの遅さや, その伝達の不徹底への批判が寄 せられている例はが 。行政が保有する情報は，住民の保 有するそれに対して多くの場合優位であるから，行政が 避難に関する勧告や指示を出すことには一定の合理性が ある。

しかしながら，避難行動に関する決定が自らの身体の 安全に関わることを考えれば，第一義的には住民が自ら 意思決定を行う権利を有することには，疑問の余地はな い。また，避難行動の決定に関する過度な行政への依存 は，自らの身体を危険にさらす可能性すらあるからであ る。この意味で, 行政からの勧告や指示を参考にしつつ, 住民が自ら自律的に避難に関する意思決定を下す必要が あろう。

本研究では, 行政等, 第三者の指示に従ってなされる 避難行動を「他律的避難」と呼び，自らの意思決定によ つて自発的になされる避難を「自律的避難」と呼ぶ。た *キーワーズ: 避難計画支援, リスクコミュニケーション, メ ンタルモデル, GIS

*学生員, 京都大学大学院情報学研究科社会情報学専攻 (京都府宇治市五ヶ生, Tel 0774-38-4037 FAX 0774-38-4044) ***正員, 工博, 京都大学防災研究所社会防災研究部門 (京都府宇治市五ヶ生, Te1 0774-38-4308 FAX 0774-38-4044)
とえ行政による避難勧告や避難指示がなされても，住民 が自らの意思によって避難に関する決定を行う場合も， 自律的避難に含める。このように自律的避難を定義つけ ると，程度の差こそあれ，ほとんどの避難は自律的避難 に分類されることになる。しかしながら，自らの意思に 従って決定された避難行動が適切な判断であり, 安全な 避難に結びつく保証もまた無い。

現状では，避難勧告や避難指示が発令されても実際に は避難しない住民は多い。また，避難のタイミングが遅 れたり, 安全でない避難場所の選択やルートの選択がな されたりする可能性もある。安全な自律的避難を実現す るためには, 各人が状況を適確に認知し, 状況に応じて 避難行動に関する適切な代替案を選択することが必要で あろう。このためには, 状況を適確に認知するための 「情報」，状況を識別するための「知識」，さらには， 識別した状況に応じて適切な避難行動を選択するための 「多様な避難行動代替案」の獲得が不可欠であるう。従 って, 自律的で安全な避難行動を実現するためには, 地 域住民が自らこれらの知識を獲得することが重要である。 しかしながら，災害はその生起頻度が少なく，経験から この種の知識を獲得することは困難である。

以上の問題意識から, 本研究では安全で適切な自律的 避難行動のための知識獲得を目指した，水害リスクコミ ユニケーション支援システム（以下，支援システム）の 開発を行うこととした。そして，住民が保有している避 難行動計画の代替案集合に関する評価を避難メンタルモ デルと呼ぶ。住民は支援システムを利用することで，自 らの避難行動計画に関する評価の妥当性を検証し，必要 に応じて自らの行動計画代替案を修正することができる。 また，支援システムを媒介としたステークホルダ間のコ ミュニケーションにより, 創発的に避難場所や避難経路, さらには，避難を開始するタイミング等に関する，より 充実した代替案集合や，状況認識のための知識を獲得す ることができるものと考える。

以下，2.では水害リスクコミュニケーションの支援の あり方に関して考察し，本研究の意義を明らかにする。 3.では本研究で構筑した支援システムについて，その概 要を述べる。4.では支援システムの検証実験の概要を示 し，5.ではその結果について述へ，考察を行う。 


\section{2. 水害リスクコミュニケーションの支援}

（1）水害リスクコミュニケーション

米国National Research Council ${ }^{4)}$ はリスクコミュニ ケーションについて,「個人, 機関, 集団間での情報や 意見のやりとりの相互作用的過程」であると定義した。 そのやりとりには，次の 2 種類のメッセージが含まれる。 1つは，リスクの性質についてメッセージ（リスクメッ セージ) である。もう1つは, リスクメッセージに対す る，またはリスク管理のための法律や制度の整㣁に対す る関心，意見，および反応を表現するメッセージである。 このNational Research Councilの定義では，少なくと もリスクメッセージの送り手とその受け手との間のコミ ユニケーションが想定されている。リスクメッセージを 送りだすためにはリスクアセスメントの技術を持つ専門 家の存在が不可欠であるから，このコミュニケーション は専門家を含む集団内で行われるコミュニケーションと なる。その根底には，リスク事象に対応するためには， リスク分析とそれに基づく双方向の対話が必要であると いう考えが存在するのである。

本研究では，水害リスクを対象として，専門家や行政， 住民等のステークホルダ相互間の対話を水害リスクコミ ユニケーションとして捉え，これまでの知見を利用して 自律的避難を実現するのに有効な対話手法の要件を探っ た。リスクを「結果」と「確率」の次元を持つベクトル として解すれば，水害リスクを対象としたリスクコミュ ニケーションにおいては, 水害の「生起確率」や, 氾濫 形態や避難の可能性，人的・物的被災状況等の「結果」 を含むリスクメッセージの提供が不可欠である。本研究 ではこれを「水害リスク情報」と呼ぶ。このように定義 すると，水害リスク情報は膨大なデー夕量となり，その 伀達は必ずしも容易ではない。そこで，水害リスク情報 を情報処理システムに格納し，必要に応じて利用しなが ら，リスクコミュニケーションを進めることとした。

（2）メンタルモデルアプローチ

災害の事前対応としての災害リスクコミュニケーショ ンでは，自然災害によるリスクの軽減がなされるべきで あることについて，多くの参加者が共通認識として有し ているという点で, 他のリスク事象に関するリスクコミ ュニケーションとは異なるといえる。安全な自律的避難 の実現を目指した水害リスクコミュニケーションにおい ても，水害リスクが軽减されるように人々の避難行動を 変容させることが，重要な命題であるといえる。よって， 避難行動を規定する住民一人ひとりの意識や知識を対象 として，その変容を図る必要がある。しかしリスクコミ ユニケーション研究によって蓄積された知見 ${ }^{5)}$ は, 一方 向的な情報提供，あるいは指示や命令によって，人々の
行動を変容させることが困難であることを示す。このこ とは，人々の行動を規定する意識や知識を，外部からの 干渉によって構筑することの難しさを示している。

本研究では，避難行動を規定する意識や知識の集合を 「避難メンタルモデル」として仮定し，その変容を図る。 メンタルモデルは人が外界に関する状況について構筑す る内的なモデル，ないしはシミュレーションであり，人 のあらゆる行動を規定しているといわれている6)。これ までのメンタルモデルに関する研究の多くは機器操作に おけるその役割を対象としており，人間が機器を操作す るときに，自分がそれまで獲得してきたメンタルモデル の枠組みで操作が行われることを示す実験結果が得られ ている(们䄈)。水害時に対応行動を迫られたとき，人の 行動が従うのはその人の持つ避難メンタルモデルである と考えると, 安全で自律的な避難の実現のために必要な のは, 事前の避難メンタルモデルに対するアプローチで ある。

（3）避蜼メンタルモデルの構造

図一1に，本研究で考える避難メンタルモデルの構 造を示す。避難メンタルモデルは水害の状況を示寸情報 の入力を受けると，それに応じて害際の避難行動を規定 すると考えられる。そして内部にはその構成要素として, 水害の状況を識別するための知識と, 避難行動計画の代 替案集合が含まれる。

例えば唯一の避難行動計画を内包した画一的な避難 メンタルモデルによって, 状況に応じた安全な避難がな されるとは考えにくい。すでに述べた通り, 安全な自律 的避難を実現するためには，住民が水害の状況を的確に 認知し, その状況に応じて適切な避難行動の代替案を選 択することが必要である。そのためには避難メンタルモ デルの内部に，より充実した避難行動計画の代替案集合 が備わっていることが望ましい。本研究ではその具体的 な項目として避難場所や避難経路，避難を開始するタイ ミングを扱う。また，外部から入力される水害の状況を 示寸情報を的確に解釈し, 多様に備わった代替案より適 切な避難行動計画を選択するためには，情報認識のため

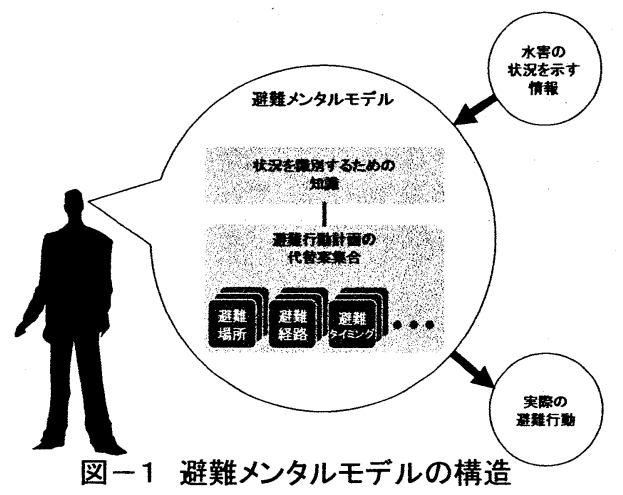


の知識の充実も不可欠である。避難メンタルモデルは, 以上の要件を満たすものと仮定し、その変化を追うこと でリスクコミュニケーションの有效性を検討することが できるものと考える。

\section{（4）避難メンタルモデルの構筑}

それでは，避難メンタルモデルを変容させるための 要件とは何であろうか。 Norman ${ }^{8)}$ は, 機器インタフェー スの設計者が留意すべきものとして，ユーザがその機器 に対して構築するメンタルモデルを仮定したが，その形 成要因を次の通り指摘した。即ち, 1. 反復経験（Learn ing by doing)，2. 観察学習, 他者との相互作用, 経 験からの類推，3. メタファ，4. 標準化である。Norman によれば，反復的な試行や学習によって，主観世界であ るメンタルモデルがより客観的な形へと変容していく。 その際, 機器のインタフェースとユーザのメンタルモデ ルとの乘離が大きいほど, メンタルモデルの構築は難し くなる。

避難メンタルモデルは, 外部からの干渉, 特に一方 向的な情報提供によってその変容を図ることは難しいと 考えられるが，反復経験や相互作用によって形成されて いくと考えることができる。しかしながら，水害を害際 に経験する機会が容易に得られるとは考えられない。た とえ水害経験が得られたとしても，それは様々な姿を見 せる水害のうち，ただ 1 つ姿を経験したに過ぎず，そ の経験によって形成される避難メンタルモデルは，画一 的なものにならざるを得ない。また，避蜼行動を観察し たり, 避難行動計画について他人と何らかのインタラク ションが発生する機会も，あまり得ることがない。そこ で本研究ではシミュレーション技術を用いて，地域住民 が様々なパターンの水害における対応行動を仮想的に体 験したり，それについて他者とコミュニケーションした りできる場を実現することによって，住民の避難メンタ ルモデルを必要な形に変容させる手法をとる。避難メン タルモデル変容のために必要なのは，水害に関する情報 や避難行動の規範の一方向的な提供ではなく，地域住民 が自分で（あるいは自分たちで），様々なパターンの水 害における避難行動を試行することができる仕組みであ る。
（5）水害リスクコミュニケーション支援システム の提案

以上の要件を満たすため, 本研究では水害リスクコ ミュニケーション支援システムを提案する。その概念を 図一2に示す。以下ではその実現方法について述べる。

a）地理情報システムの利用

本研究では水害リスク情報として, 汇濫解析の結果 を利用する。解析による氾監予測の精度は著しく向上し， 水害時の避難行動の結果を推定する際に有効であると考 えられる例えば 9)。氾濫解析の結果である時系列浸水深デ 一夕は地理的な座標, 時間, 浸水深等を含み, これを扱 うには 4 次元以上の情報空間を用意する必要がある。ま た，時系列浸水深データを氾濫シナリオごとに扱うとす ると，その膨大なデー夕量に留意しなければならない。 そこで支援システムには，時系列地理データの扱いに長 ける時空間地理情報システム, DiMSIS ${ }^{10)}$ を利用するこ ととした。

b）避難行動に関する仮想タスク空間の実現

黑川 ${ }^{11)}$ は，人間が情報機械とインタラクションを行 う際の作業対象が存在する空間を, 仮想タスク空間と名 付けた。そして人間が仮想タスク空間内の仮想対象とコ ミュニケーションを行う際には, 脳の記憶力, 推論力, 表現力がデータベースやシミュレーションの形で情報機 械上に外化され，人は新たな思考力と想像力を獲得でき るとする。

支援システムはその要件により, 地域住民が考える 水害時の避難行動を, 自ら試行することができる場を提 供する必要がある。本研究ではそのための場として, 水 害時の避難行動に関する仮想タスク空間を実現する。ユ 一ザは支援システム上に, 自らの考える避難行動計画を 投影し，さらにその結果に関する情報を得ることができ る。支援システムは，水害リスク情報を用いて入力され た避難行動を評価し，様々なシナリオにおける安全性と いう形でその結果を示す。このように, 経験することの 難しい様々な形の水害におけるその対応行動を, 繰り返 し仮想的に体験することによって, 人の避難メンタルモ デルの内部に, 避難行動計画の代替案集合や水害の状況 を識別するための知識が，自律的に形成されると考える。

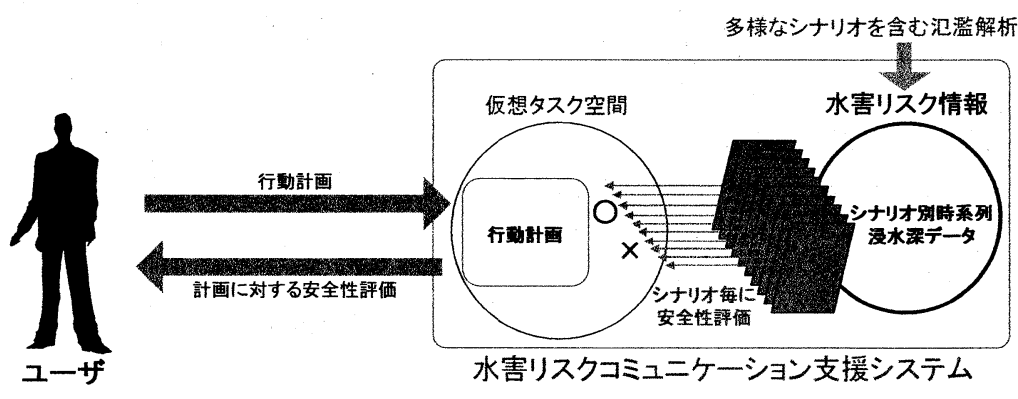

図ー2 水害リスクコミュニケーション支援システム概念図 
（6）既往研究のレビューと本研究の立場

メンタルモデルの概念を用いたリスクコミュニケー ションに関する研究としては, Granger ${ }^{12)}$ らによるもの が挙げられる。彼らはリスクコミュニケーションにおい て効果的に情報提供を行うために，人々のリスク事象に 関するメンタルモデルをインタビューによって図式化し， 提供すべき情報を探る手法を提案している。

災害に対する事前の被害軽減策として，住民の防災 意識の向上を図る情報処理システムは, いくつか挙げる ことができる。飯田ら ${ }^{13)}$ は，岐阜県大垣市を対象とし た内外水を含む氾濫解析を用いて，防災計画を検討寸る ためのツールを開発した。飯田らはこのツールを, 防災 訓練や防災教育に応用できると述べる。また片田ら ${ }^{14)}$ は，津波災害に関する防災教育を目的として，津波災害 時における行政の対応行動や住民の避難行動を総合的に 表現した，津波災害シナリオ・シミュレータを開発した。 これらの住民に対する防災教育を想定したツールは，い ずれも一方向的に情報提供を行う仕組みになって いる。よって住民が自らの考える避難行動計画を投影 し，その結果に関する情報提供を受けるための十分な機 能を備えているとは言えない。また目黒ら ${ }^{15)}$ は，ユー ザが没入的に地下街における避難の样子を体験すること を目的として，仮想現実感技術を用いた避難シミュレー ションを開発した。しかし，ユーザ自身による操作の可 能性や，適用事例については示していない。

藤井 ${ }^{16)}$ は, 公共交通による移動の保証や道路混雑の 緩和を目的として，コミュニケーションによって人々の 移動を過度な自動車利用から適切な公共交通の利用へと 誘導する「モビリティマネジメント」を提案し，成果を 挙げている。コミュニケーションによって人の内部モデ ルに対してアプローチし, 行動の自発的な変化を誘発す るという手法は，本研究と共通する。

本研究では, 水害時の人の避難行動を規定する避難 メンタルモデルを仮定し, その内部に避難行動計画の代 替案集合や水害状況を識別するための知識を充実させる ことを目指す。このように避難メンタルモデルを変容さ せるためには，一方向的な情報提供によらず，住民自ら が様々な避難行動を仮想的に体験できる場を提供する必 要があった。水害リスクコミュニケーション支援システ 么は，地域住民が考える避難行動計画の自発的な試行を 可能にし，行政が持つ水害リスク情報との双方向的なイ ンタラクションや, 避難行動に関する他者とのコミュニ ケーションを実現する。この意味で，支援システムは防 災教育ツールではなく，行政と地域住民をステークホル ダとするリスクコミュニケーション支援ツールであると いえる。

\section{3. 水害リスクコミュニケーション支援システムの構築}

（1）支援システムの適用地域

本研究では支援システムの適用地域を, 愛知県の新 川流域と定めた。具体的には，旧西枇杷島町，旧新川町， 名古屋市西区・北区の庄内川以北の，4つの地域である。 これらの地域は 2000 年東海豪雨災害において, 甚大な 被害が発生した。これを受けて平成 12 年度より総額 719 億円に上る緊急的な治水事業, 「河川激甚災害対策 特別緊急事業」が 5 力年かけて実施され ${ }^{17)} ， 2000$ 年当 時と比べて沉濫の可能性は低くなったといえる。しかし ながらその地形的な特徵より，この地域における水害の 危険性が本質的に去ったとは考えられず，再び大きな洪 水に見舞われれば，人的被害の発生が懸念される。

（2）汇濫解析について

辻本ら ${ }^{18)}$ は新川を対象として，複数のシナリオを含 み, 内水・外水を連動して取り扱える氾濫解析を構築し た。本汇濫解析は，内水氾濫から破堤を伴う大規模な複 合汇濫まで, 合計 68 種の水災シナリオを備える。

氾濫解析の結果を擁する愛知県河川課は, 地域住民 に対する水害危険度情報の周知一の利用可能性を検討し ていた。そこで, 支援システムに対して氾濫解析の結果 を提供していただけることとなった。

(3) 支援システムの構成

支援システムの構成を, 図一3に示す。支援システ ムは, 松本ら ${ }^{19)}$ によって参加型洪水リスクマネジメン トを目的として開発された情報处理システム（以下，既 存システム）を利用して構筑された。今回新たに追加し たモジュールやデータは，図ー3において新規部分とし て示されている。

DiMSIS は，時空間情報を扱うことができる時空間地 理情報システムである ${ }^{10)}$ 。氾濫解析の結果であるシナ リ才別時系列浸水媣や各種の地理デー夕は, DiMSIS の 地理デー夕領域に格納される。特に時系列浸水深は, 位 置情報に時間情報が統合された時空間情報として構成さ れることになる。

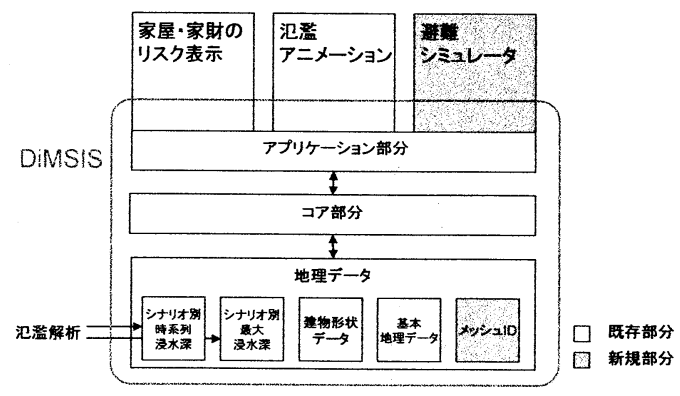

図ー3 支援システムの構成 
これら地理データは DiMSIS のコア部分が制御し、コア 部分はアプリケーションにおいて呼び出される。DiMSIS には元来, 地理情報を扱うための基本的なアプリケーシ ヨンが備わっており，既存システムではこの上に，家 屋・家財のリスク表示機能や氾濫アニメーション機能を 実現する業務アプリケーションが構築されていた。

本研究では, 地域住民の考える避難行動計画を投影で きる仮想タスク空間を提供するために，既存システムに 避難シミュレータ機能を実現する業務アプリケーション と，そこで必要となるメッシュ ID データが追加された。 このように, 避難シミュレータは既存システムのリソー スを利用しながら，水害リスクコミュニケーション支援 システムの要件を満たすべく，その中核となる機能を提 供するものである。

\section{（4）避難シミュレータ}

図ー4に避難シミュレータの操作フローを示す。基 本的には, ユーザは個人属性, 避難のタイミング, 避難 場所，避難経路の順で入力を行う。避難シミュレータは 入力された避難に対して, 全てのシナリオにおける安全 性評価と, シナリオ別避難アニメーションの 2 種類の出 力を提供する。以下では各操作・出力の概要と, それぞ れの要件定義について述べる。

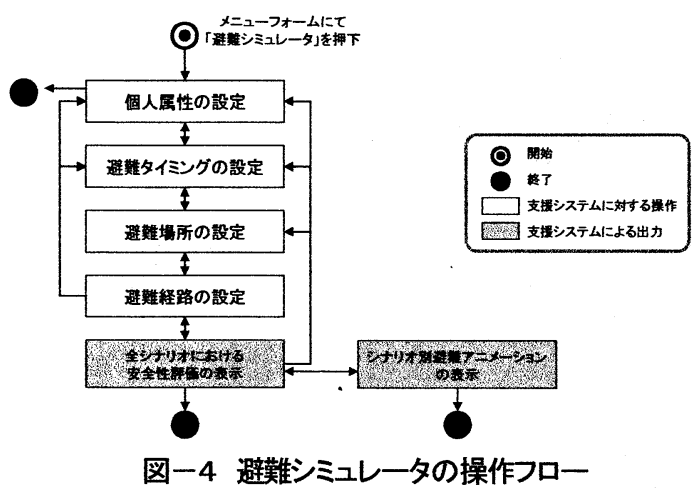

a）個人属性の設定

ユーザはまず，自分の身長と避難時の歩行速度を設 定する。歩行速度は任意に設定することができるが，設 定フォームではその参考值として，地震防㷋計画で想定 されている避難速度である $2.016 \mathrm{~km} / \mathrm{h}$ 之 ${ }^{20)}$, 吉岡 ${ }^{21)}$ の 調查による通勤時の平均歩行速度, $1.9958 \mathrm{~km} / \mathrm{h}$ が提案 される。

b）避難タイミングの設定

避難行動計画の結果を左右する大きな要因の 1 つに, 避難のタイミングが挙げられる。避難シミュレータでは, 避難のきっかけとなる情報と，情報の取得から避難行動 を開始するまでの時間の入力によって, 避難タイミング を決定している。なお，本研究では避難のきっかけとな
る情報を，「避蜼トリガ」と呼ぶ。

安全な自律的避難を実現しうる避難メンタルモデル には，水害の状況を示す情報を的確に識別するための知 識が備えられなければならない。のため避難シミュレ 一夕は，氷害時に住民が取得できる避難トリガを，入力 として多様に取り扱う必要がある。現状の避難トリガと しては，市町村が発表する避難情報や，都道府県と気象 庁が合同で行う洪水予報が考えられる。さらに近年，リ アルタイム河川情報 ${ }^{22)}$ の整備が全国に広まっており， インターネットを介した情報取得も，その選択肢として 考えることができる。リアルタイム河川情報では，流域 雨量と河川の水位が 10 分毎に更新される。このような システムの整備は直轄河川だけにとどまらず，近年では 都道府県管理河川にも広がりを見せている。そして一部 では，携帯電話端末向けの web サイトでも，同様の情報 提供が始まっている例えば23)。

以上より避難シミュレータでは，避難情報や洪水予 報に加え, 地域住民がインターネットを介して河川の水 位や流域雨量に関する情報も取得できることを想定し， それらの值を避難トリガとして設定することができる。 その設定フォームの一例を, 図一5に示す。避難シミュ レータには汇濫解析における河川の水位と流域雨量情報 が，シナリ才別に時系列情報として格納されている。ユ 一ザが避難トリガとして水位や雨量を設定すると，これ らの時系列情報を利用して, シナリオ別に避難タイミン グが決定される仕組みとなっている。

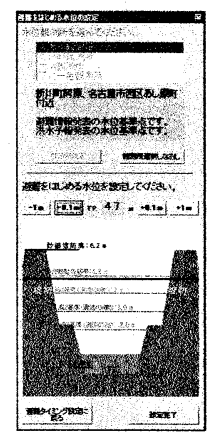

$\mathrm{A}$ 水位の設定

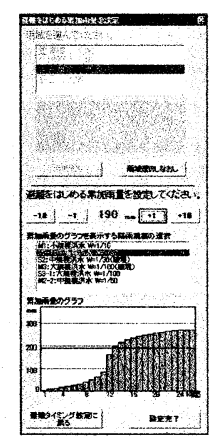

$\mathrm{B}$ 雨量の設定 c）避難場所・避難経路の設定

次に，ユーザは避難場所と避難経路を設定する。その設 定画面の一例を，図一6に示す。避難場所は地図画面上 で任意に設定することができるが，指定避難所や公的施 設，あるいは鉄筋造のマンションなどが，その階数と共 に提案される。また，避難経路についても地図画面上で 任意に点を設定し，経路を構成することができる。

地理情報システムを用いる以上, 地理データとして 道路ネットワークを統合し, 空間解析によって自宅の 


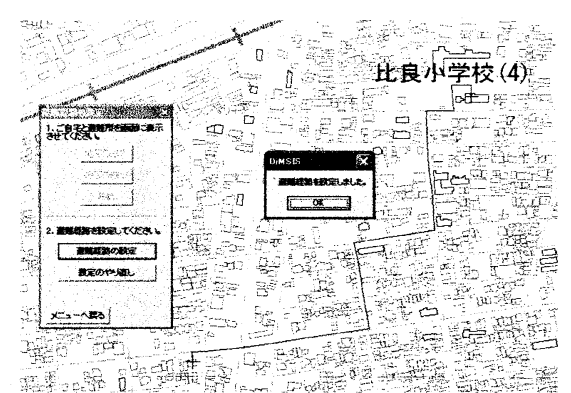

図-6 避難場所と避難経路の設定画面

最近傍に位置する指定避難所とそこに至る最短経路を算 出したり，水害リスク情報に照らして安全度が高いと思 われる避難場所と避難経路を算出して，ユーザに提案す ることはできる。しかしながらこのように一方的に答え を与えてしまえば，双方向的なインタラクションや，さ らにはコミュニケーションが発生するとは考えにくい。 また，特に避難経路の選択は，行政による指導や客観的 な安全性を反映せずに，主観的になされているのが実態 である例えば 24)。以上より避難シミュレータは，避難場 所と避難経路を，建物データや道路ネットワークなどの 地理データに制限されずに，地図上において任意に入力 できるインタフェースを備える。

d）安全性の評価

須賀ら ${ }^{25)}$ は; 浸水が水中歩行に与える影響について 実験を行った。その結果，その水深が膝高までの場合に は, 流速と関係が少なくほぼ一定の速度で歩行すること ができた。また，水深が膝高を超えると歩行速度が急速 に低下し，恐怖感も感じはじめる，と述べる。須賀らの 実験は, 膝高以上の浸水ではもはや安定して歩行するこ とができず，安全な避難は望めないことを教えてくれる。 よって本研究では, 避難において辛うじて歩行が可能な 水深を, 人の膝高と定める。

避難シミュレータでは, 安全性の評価を次の 3 段階 で表記する。避難途上で浸水に遭遇しない場合は○，膝 高までの浸水がある場合は $\triangle$ ，膝高を越えて浸水する場 合は×と定めた。人の膝高を推定するにあたっては， 独立行政法人情報通信研究機構による数值人体モデルの 無償利用サービスを利用した。数值人体モデルは日本人 の平均体型を表しており，その再現性は非常に高いとい える ${ }^{26)}$ 。数值值人体モデルにおける膝高は身長の約 $26 \%$ 位置にあり，避難シミュレータはユーザの身長の 入力によりその膝高を推定し, 安全度の評価を下寸こと と寸る。なお，須賀らの実験結果や，緑川水系御舟川昭 和 63 年 5 月洪水における避難行動に関寸る調査結果 27) からは，膝高までの浸水深においては避難速度と浸 水との間に因果関係が薄いことを示している。よって避 難シミュレータでは, 膝高以下の浸水においては一定の 避難速度を保てると仮定し, 避難速度の割引等は行わな
いこととする。

以上の方法により, 避難シミュレータは入力された 避難行動の安全性の評価を行う。図一7に, そのフォー ムを示す。フォームでは, 左側において氾濫シナリオ毎 の安全性の判定が示される。そして氾濫シナリオの選択 によって, そのシナリオにおいて遭遇する最大浸水深が, 数值と人体図を用いたイメージによって, フォームの右 下部分に示される。

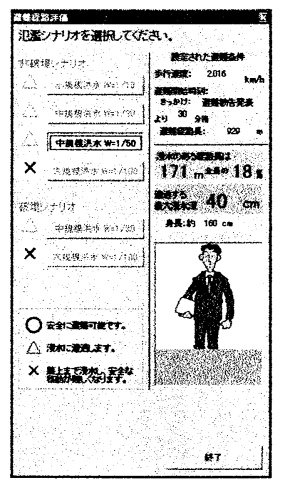

\section{図ー7 避難行動の安全性評価フォーム}

e）避難アニメーション

さらにユーザは, 入力した避難行動の様子を, 氾濫 の様子とあわせて時系列に沿って確認することができる。 その表示画面の一例を, 図一8に示す。

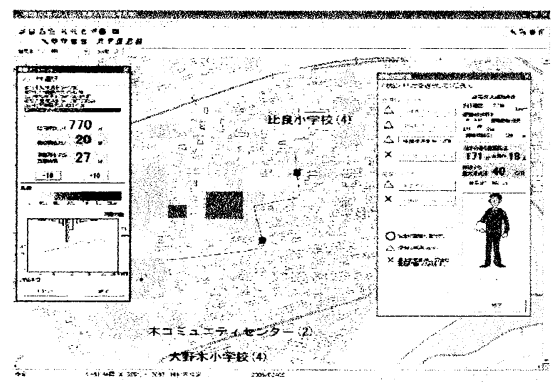

図ー8 避難アニメーション表示画面

\section{4. 検証実験について}

(1) 検証実験の目的

本実験は，地域住民の避難メンタルモデルの変容に 対する，支援システムの有効性を検証するものである。 実験では避難メンタルモデル形成の要件を踏まえ, 検証 項目を以下の通り 3 つ設定する。すなわち，1．地域住 民が自らの考える避難行動計画を，支援システムの避難 シミュレータにおいて正確に投影することができるか， 2. 避難シミュレータにおける試行の結果, 地域住民が 備える避難行動計画の代替案の充実が見られるか， 3. 支援システム利用の結果，水害の状況を識別するための 知識や，地域における水害に対する認識が変化するか， 
の3つである。これらの項目を検証するため, 本研究で は支援システムが対象とする地域において検証実験を行 うこととした。実験は水害に関するワークショップとし て実施され，地域住民の方々に参加していただいた。そ して参加者の方に支援システムを利用してもらい，その 前後における意識の変化や, 利用の実態について調査を 行った。

\section{(2) 検証実験の概要}

検証実験は 2 回にわたって実施された。その様子を 写真一 1 に示す。

1 回目は 2006 年 2 月 2 日, 愛知県清須市須ヶ口の豊 和工業株式会社の厚生会館にて行われた。支援システム は 2 台のコンピュータに実装され, 参加者は $1 \sim 4$ 人ず つ1台のコンピュータに向かい, タスクを行った。参加 者は $3 \sim 5$ 人ずつを 1 グループとして, 計 5 グループ, 総勢 21 名が参加した。参加者が支援システムを利用す るときは, ワークショップのファシリテータが補助を行 い，多くの場合その入力作業を代替した。なお以下では， 1 回目の検証実験の参加者のグループを, グループ A と 呼ぶことにする。

2 回目は 2006 年 2 月 3 日, 愛知県清須市西枇杷島町 の旧西枇杷島町社会福祉協議会の施設, 「数いの家」に おいて実施された。支援システムの出力はプロジェクタ によって会場の正面に映し出され，13 人の参加者全員 が投影された画面を共有しながらタスクを行った。支援 システムへの入力操作と, ワークショップの司会進行は ファシリテータが行った。以下では 2 回目の検証実験の 参加者グループを, グループB と呼ぶ。
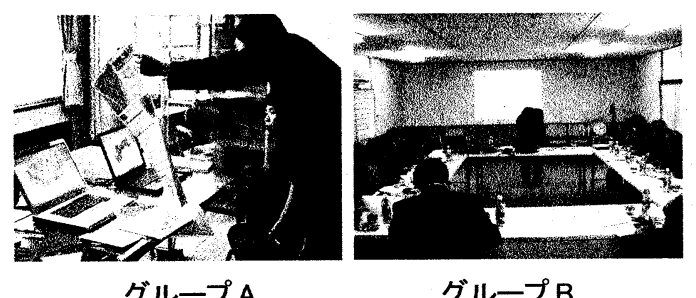

$$
\text { グループA }
$$

グループ B

\section{写真 -1 検証実験の様子}

（3）参加者の属性

グループ A の参加者の約 80\%は旧新川町に居住してお り，またグループB の参加者は，その全員が旧西枇杷島 町に居住している。両グループの参加者は同様の年齢構 成を見せ，その約 4 割が 60 歳代，約 3 割が 70 歳代であ った。なお参加者の居住地域はいずれも，2000 年東海 豪雨災害時に甚大な被害が発生した地域であり，ほとん どの参加者がなんらかの形で被災を経験していた。

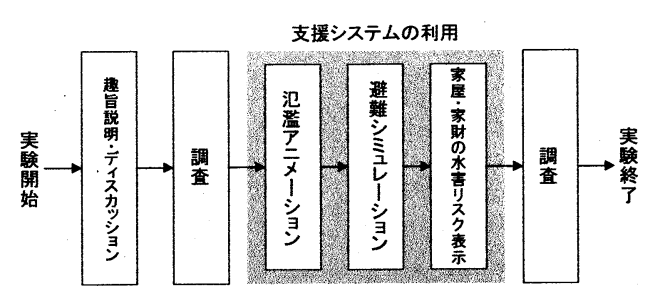

図一9 実験の流れ

（4）検証実験の流れ

実験ではグループ A，B 共に，図一9に示す流れをた どった。参加者にはまず実験の趣旨説明を行い，それに 続いて地域の水害の危険性について, 参加者と共にディ スカッションを行った。その際には参考資料として, 洪 水ハザードマップを利用した。次に調査を行い，支援シ ステムの利用に入った。そして最後に再度調查を行い， 実験を終了した。調查の詳細については後述する。

支援システムの利用では，基本的には図一9に示す とおり, 氾濫アニメーション, 避難シミュレーション, 家屋・家財の水害リスク表示の順で機能を稼動させた。 氾濫アニメーションの稼動では, 小規模洪水から大規模 まで，様々な洪水シナリオにおける汇監の様子を地域の 地図上において表示させ，参加者はシナリオごとに氾濫 の変化を確認した。次に避難シミュレータを用いて, 参 加者ごとに 1 回目の調查で明らかになった避䧼行動計画 の安全性を確認していき，あわせて入力された避難と汇 濫の時系列変化を避難アニメーションにて確認した。こ れを受けて参加者は避難行動計画を変化させていった。 参加者の意向によって避難シミュレータに入力するパラ メータが繰り返し変更され，様々な試行が行われた。

最後に一部の参加者は, 家屋・家財の水害リスク表 示機能を利用した。グループA で本機能を利用した参加 者は 3 人,グループBにおいては 4 人であった。本機能 の利用者は実際に地図上で自宅を選択し, 家屋と家財に 対する水害リスクを確認した。その様子は参加者グルー プ全員で共有された。

\section{（5）調查方法}

実験では支援システムを利用する前後において，参 加者に対して計2回調査を行った。調査では質問用紙と 回答用紙が配布され，参加者はその場で回答した。

調查における質問項目を，表一 1 に示す。2回の調査

\begin{tabular}{|c|c|}
\hline \multicolumn{2}{|r|}{ 表一1 質問項目 } \\
\hline 調查 & 質問項目 \\
\hline $\begin{array}{c}\text { 支援システム } \\
\text { 利用前 }\end{array}$ & $\begin{array}{l}\text { 個人属性 } \\
\text { 2000年東海豪雨災害における被災体験 } \\
\text { 洪水ハザードマップの所持実態 } \\
\text { 水害に対する認識 } \\
\text { 避難行動計画(避難のきっかけ，場所，経路) }\end{array}$ \\
\hline $\begin{array}{c}\text { 支援システム } \\
\text { 利用後 }\end{array}$ & $\begin{array}{l}\text { 水害に対する認識 } \\
\text { 避難行動計画(避難のきつかけ，場所，経路） } \\
\text { 支援システムに対する意見·感想 } \\
\text { 自由回答欄 }\end{array}$ \\
\hline
\end{tabular}


において，「水害に対する認識」の項目と「避難行動計 画」の項目は共通しており，支援システムの利用による 参加者の避難メンタルモデルの変化を類推できるように 設定した。なお「水害に対する認識」を問う項目では, 今後自宅が浸水する可能性に関する意識を, 床上浸水・ 床下浸水それぞれについて聞いた。また「避難行動計 画」については, 水害時の避難先として考えている全て の場所と, そこに至るまでの経路を, 参加者の自宅周辺 の道路地図上に描いてもらった。それとあわせて避難を 考え始めるきっかけと, そのきっかけから実際に避難を 始めるまでのおおよその時間について調査した。

\section{5. 検証実験の結果と考察}

（1）避難シミュレータにおける避難行動計画の投 影状況

まず 4. で示した検証項目のうち，1 つ目について述 べる。検証実験では，地域住民が考える避蜼行動計画を， 避難シミュレータが備える機能の制限によって投影でき なかった事例は存在しなかった。行動計画には避難場所 として堤防の上やスーパー, 変電所, 街道などを含むも のがあったが，すべて地図上で任意に選択することがで きた。また避難経路に関して見ると, 多くは自宅から避 難場所までの最短経路などではなく, 自身が考える水害 時の安全度を考虑した経路や, 普段通りなれた経路, あ るいは空き地や耕作地などを通る「道なき道」が選択さ れている。このような避難経路についても, すべて避難 シミュレータに入力することができた。

以上より, 検証実験では地域住民の考える避難行動 計画を避難シミュレータ上に投影するのに, 大きな支障 がないことが示されたと考えられる。この点は，住民が 考える避難行動計画に対して支援システムがその結果を 返し, 両者の間で双方向のインタラクションを行ってい く上で, また, 複数の住民が自分たちの考える避難行動 計画に関してコミュニケーションを行うために, 避難シ ミュレータが備えるべき条件として重要な意味を持つ。

\section{（2）避難行動計画の代替案の充害}

ここでは検証項目 2 について述べる。実験では, 代替 案の多様化を示寸事例をいくつか見ることができた。以 下では2つの事例を示し，それぞれについて考察を行う。

a）試行による新たな避難行動計画の獲得事例

グループB では支援システム利用前後の調査によって, 13 人の参加者（調査の有効回答数 : 12) のうち 5 人が, 新たな避難行動計画を示した。この 5 人が支援システム 利用前に示していたのは指定避難所や堤防上への避難行 動計画であったが，新たな行動計画の多くは，比較的大 規模な水害における一時避難を目的とした，鉄筋コンク
リート造で 4 階建以上の建物であった。

避難シミュレータに対して堤防上への避蜼行動計画が 入力されると，堤防上は内水汇濫によって早い段階で孤 立し，逃げ場がなくなる様子や，大規模な水害時には溢 水による堤防上の危険性が顕著に示された。また指定避 難所一の避難行動計画に対しても，ある規模以上の水害 においては指定避難所自体が決して安全ではない状況が， 避難シミュレータによって示された。このような試行の 末に，比較的大規模な水害を想定した一時避難場所の必 要性に関する議論が発生し, 地域においてある程度の高 さと強度を持つ建物一の避難が検討され始めた。

この事例では参加者の約4割において, 新たな避難行 動計画の獲得を見ることができた。参加者は様々な計画 を試していく過程を経て, 自分たちで安全だと思われる 行動計画を見つけ出し，獲得したといえる。この結果に 対しては，自身が考える避難を投影し，それについて評 価を受けることができるという避難シミュレータの持つ 機能が，大きな役割を果たしたと考えることができる。

b) 支援システムを媒介としたコミュニケーション事 例

グループAでは，旧新川町の名鉄線以南に居住してい る被験者の間で, 清須市によって避難所に指定されてい る桃栄小学校に関する議論が活発に行われた。支援シス テムに統合された氾濫解析結果によると, 桃栄小学校で は早い段階で，その周りを取り囲むように氾濫が発生す る。しかし支援システム利用前の調查においては，この 地区に住むほとんどの参加者が桃栄小学校への避難行動 計画を回答した。

桃栄小学校への避難がシミュレータに入力されると, その多くは膝高以上の氾濫に遭遇し, 安全に避難できな いという評価が下され，あわせて避難衔告が出された時 点において，すでに孤立する桃栄小学校の姿が示された。 その表示画面を図一 10 ○示す。結果は同じ地区に住む 5 人の参加者によって共有されており, 参加者からは 2000 年東海豪雨災害時において桃栄小学校に避難を行 い，その途上で腰まで水に浸かった体験や，周囲より高 くなっている美濃街道を通るべきだという意見がだされ た。これを受けて避難シミュレータ上では美濃街道を通 る新たな避難行動計画が試行され，氾濫解析における

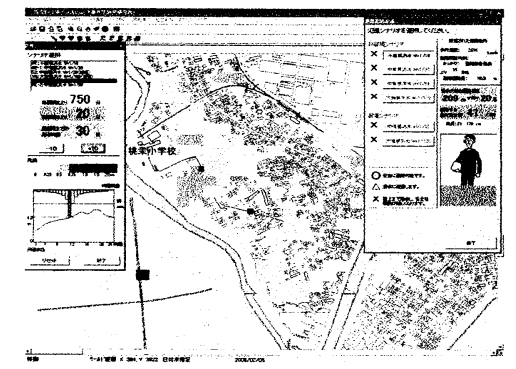

図ー10桃栄小学校への避難に対する評価画面 
美濃街道の安全性が確かめられた。以上の試行を踏まえ て, 桃栄小学校が避難所として指定されていることにつ いての問題や，美濃街道沿いに一時避難所を設置する案， さらには, 須ヶ口駅を地区の一時避難所として指定する 案が提唱された。

このように, 実験では同じ地区に住む参加者の間で 避難に関する活発な議論が発生し, 新たな避難行動計画 が提晿され，共有されていく様を見ることができた。注 目すべきは，洪水ハザードマップによってこれらの議論 を引き出すことができなかった点である。主体的で活発 な議論が醸成された要因を考えると, 避難シミュレータ による動的に変化する避難行動と浸水の表示や，樣々な 氾濫シナリオを含む情報，そしてなによりも自分たちの 考える避蜼行動を投影し，その結果を知るという行為そ のものが，大きく影響していたと考えられる。これらの 要因については, さらなる実験によって検証していくこ とが必要である。

（3）状況識別のための知識

ここでは避難行動計画において設定された，避難トリ ガに対する認識の変化を見ることにする。支援システム 利用前の調查では, 両グループにおいて参加者のほぼ全 員が避難勧告を避難トリガとして設定した。しかし避難 シミュレータによって, 避難勧告発表時には既に各地で 内水汇濫が発生する様子が伝えられ，多くの参加者は避 難準備情報を避難トリガとして設定した。また支援シス テム利用後の調査における自由解答欄には, 早い段階で 浸水する可能性や, 避難を早める必要性を感じたという 回答がいくつか見られた。これらの事例から，参加者の 多くは避難シミュレータを用いた試行により, 避難勧告 をトリガとした避難が必ずしも安全でないという認識を 獲得したものと思われる。

避難シミュレータによれば，避難淮備情報の発表は避 難勧告の発表よりも 2〜5 時間早まる。多くの参加者に とって,これほど早い段階の避難は現実的でなかったよ うである。このことは状況を適確に認知するための情報 が，現状では非常に乏しいものになっている可能性を示 唆する。もしそうだとすれば, 水害時に地域住民が避難 行動を選択するきっかけとなる情報について，さらなる 充実を検討する必要がある。

（4）浸水可能性に関する意識の変化

支援システム利用の前後における調查では，水害に 対する認識として今後の自宅浸水の可能性が, 床下浸水 と床上浸水のそれぞれについて参加者に問われた。この 設問に対しては，「1:絶対遭わない」から「7:絶対遭 う」までの 7 段階で回答がなされた。有効回答数はグル 一プA が 19 人，グループ B が 9 人であった。本設問に
対する回答の平均値の，支援システム利用の前後におけ る変化についてグループ毎に検証した。表一2に示寸と おり，床下・床上浸水のいずれにおいても回答の平均值 は上昇した。

この結果は，支援システムの利用によって水害に対 する意識が向上したことを示すと考えられる。例外的に グループB の参加者における床上浸水に対する回答では, 有意な差が見られなかった。グループ B では全ての戸建 て居住者が, 2000 年東海豪雨災害において床上浸水に 見舞われている。この被災体験によってグループBの参 加者は，比較的高い意識を備えていたと考えられる。

\section{表-2 浸水可能性の設問に対する回答の平均値}

\begin{tabular}{|l|c|c|c|c|}
\hline & \multicolumn{2}{|c|}{ グルプA } & \multicolumn{2}{c|}{ グループB } \\
\cline { 2 - 5 } & 床下浸水 & 床上浸水 & 床下浸水 & 床上漫水 \\
\hline システム利用前 & 5.42 & 4.84 & 5.56 & 6.00 \\
\hline システム利用後 & 6.05 & 5.74 & 6.56 & 6.56 \\
\hline 利用前後の差 & $+0.62 *$ & $+0.90 *$ & $+1.00 *$ & +0.56 \\
\hline *5\%水準で有意
\end{tabular}

\section{6. おわりに}

安全な自立的避難の実現を目指し，地域住民の避難 メンタルモデルの変容を図るため, 水害リスクコミュニ ケーション支援システムを開発した。支援システムには， 住民が自分で避蜼行動計画を試行するための機能を備え た，避難シミュレータが実装された。本論文ではさらに， 支援システムの有効性を検証するための実験について報 告を行った。実験では地域住民が自らの考える避難行動 計画を，避難シミュレータ上に正確に投影できることが 確認された。また, 地域住民が備える避難行動計画の代 替案の充実や, 水害の状況を識別するための知識の獲得, 水害に対する認識の獲得に対して, 避難シミュレータの 有効性が確認された。

しかしながら検証実験は，被験者のサンプル数の不 足やグループによる実験環境の違いなどの問題を含んで いる。また，観測された効果の持続性についても不明で ある。今後さらなる調査・実験を行い，支援システムに よる効果を定量的に検証していく必要があると考える。

実験では，多人数による操作や情報共有を円滑に行 うための, 新たな入出力装置の必要性が浮き彫りとなっ た。これについては，紙地図上にプロジェクタを用いて 支援システムの出力を投影する手法が有効であると考え られる。また支援システムに，ユーザによる避難行動計 画の試行や，それによって発生した議論をその場で印刷 物として出力する機能を, 新たに追加することも考えら れる。印刷物をその住民固有の「マイ・ハザードマッ プ」として家に持ち帰ってもらえば，獲得された避難行 動計画の定着を図ることができると思われる。 


\section{参考文献}

1）国土交通省河川局 : 平成14年度版水害統計，2001

2）佐藤照子：2000年東海豪雨災害における都市型水害被害の 特徴について, 防災科学技術研究所主要災害調査, Vol. 38, pp. 391-409，2002

3）牛山素行: 2004年7月12～13日の新潟県における豪雨災害 の特徵, 自然災害科学, Vol. 23, No. 2, pp. 293-302, 2004

4）林裕造・関沢純（監訳），National Research Counci1 (編) : リスクコミュニケーション一前進への提言一，化 学工業日報社, 1997

5）吉川肇子 : リスク・コミュニケーション一相互理解とより よい意思決定を目指して一，福村出版，1999

6) K. J.W. Craik : The nature of explanation, Cambridge : At the University Press, 1943

7) Kieras, D.E. \& Bovaer, S. : The role of a mental model in learning to operate a device, Cognitive Science, Vol. 8, pp. 255-273, 1984

8) D. A. Norman, S. W. Draper (Eds. ) : User centered system d esign New perspectives on human-computer interaction, Hillsdale, NJ, Erlbaum Associates, 1986

9）舘健一郎，武富一秀，川本一喜，金木誠，飯田進史，平川 了治, 谷岡康 : 内水を考慮した汇濫解析モデルの構筑と検 証一大垣市を対象として一，河川技術論文集，Vol. 8，200 2

10）畑山満則, 松野文俊, 角本繁, 亀田弘行 : 時空間地理情 報システムDiMSISの開発，GIS-理論と応用，Vol. 7, No. 2, 1999

11）黒川隆夫 : ノンバーバルインタフェース, オーム社, 19 94

12 ) M. Granger Morgan, Bruch Fischhoff, Ann Bostrom, Cyn thia J. Atman : Risk Communication A Mental Models Ap proach, Cambridge University Press, 2002

13 ）飯田進史, 舘健一郎, 武富一秀, 川本一喜, 金木誠, 平 川了治, 谷岡康 : 水害時の避難解析システムの構築と危機 管理対応支援一の適用性検討，河川技術論文集，Vol8，20 02
14）片田敏孝, 桑沢敬行, 金井昌信, 細井教平 : 津波災害シ ナリオ・シミュレータを用いた尾鷲市民への防災教育の実 施とその評価，社会技術論文集，Vol.2，pp199-208，2004

$15 ）$ 目黒公郎, 藤田卓 : ポテンシャルモデルとVRを組み合わ せた新しい避難シミュレーションツールの開発, 東京大学 生産技術研究所生産研究, Vol. 54, No. 6, pp43-46, 2002

16 ) 藤井聡 : モビリティ・マネジメント, 新都市, Vol16, N o. 2, pp. 17-24, 都市計画協会, 2004

17 ）愛知県河川工事事務所 : 平成 12 年 9 月東海豪雨災害新川 河川激甚災害対策特別緊急事業の概要, 2005

18 ）愛知県氾濫シミュレーション技術検討会 : 水災シナリオ に即した浸水情報の在り方, 愛知県氾濫シミュレーション 技術検討会総合報告書, 2004

19）松本卓也，多々納裕一，岡田憲夫，川嶌健一 : 時空間GI Sを利用した参加型洪水リスクマネジメントのためのシス テム設計及び実装, 第 23 回日本自然災害学会学術講演会 講演概要集, 2004

$20 ）$ 建設省士木研究所河川部総合治水研究室 : 水害時の避難 行動に関する調査報告書一緑川水系御船川昭和63年5月洪 水における避難行動一, 土木研究所資料第2862号, 1990

2 1）吉岡昭雄 : 市街地道路の計画と設計，技術書院，1998

22）国土交通省河川局 : リアルタイム川の防災情報, http:/ /www. river. go. jp/, 2006

23 ）愛知県企画振興部情報企画課 : モバイルネットあいち, http://mobile. pref. aichi. jp/mgwnw/m/imode. html, 2006

24 ）建設省土木研究所河川部都市河川研究室 : 関川水害時の 避難行動分析，土木研究所資料第3536号，1998

25 ）須賀克三 : 避難時の水中歩行に関する実験，水工学論文 集, Vol. 39, pp. 879-832, 1995

26 ）長岡智明，櫻井清子，国枝悦夫，渡邊聡一，本間寛之， 鈴木保, 河合光正, 酒本勝之, 小川孝次 : 日本人成人男女 の平均体型を有する全身数值モデルの開発，生体医工学， Vol. 40, No. 4, pp. 45-52, 2002

27 ) 建設省土木研究所河川部総合治水研究室 : 水害時の避難 行動に関する調查報告書 緑川水系御船川昭和63年5月洪 水における避難行動一，土木研究所資料第2862号，1990

\section{自律的避難のための水害リスクコミュニケーション支援システムの開発*}

$$
\text { 川嶌健一**・多々納裕一***・畑山満則 } \mid * * *
$$

安全な自律的避難を実現するためには，状況を適確に認知するための「情報」，状況を識別するための「知識」，さ らには, 識別した状況に応じて適切な避難行動を選択するための「多様な避難行動代替案」の獲得が不可欠であろう。 本研究では人々の水害時の避難行動を規定する避難メンタルモデルを仮定し, その中に多様な避難行動代替案の形成 を図るため, 水害リスクコミュニケーション支援システムの開発を行った。愛知県清須市で行われた支援システムの 検証実験では，地域住民の持つ水害状况に対する認知や避難行動の代替案集合の多様化が見られ，その効果が確認さ れた。

\section{A Flood Risk Communication Support System to Promote Safe Autonomous Evacuation*} By Kenichi KAWASHIMA**·Hirokazu TATANO***-Michinori HATAYAMA***

To realize safe autonomous evacuation, citizens should obtain well developed "mental model" for evacuation which includes appropriate perception mechanism to preserve flood risk and flexible "altermative set" for evacuation actions. Aiming at const ructing well developed mental models which citizens' evacuation actions are determined based on, the paper develops a floo d risk communication support system. Through communication among stakeholders assisted by the system, changes in flood risk perception and increase in the flexibility of the alternative plans of evacuation actions are observed in the experimental workshops in Kiyosu City, Aichi prefecture. 